Note

\section{Distribution of Cysteamine Dioxygenase in Animal Tissues}

\section{Hiroyuki KataoKa, * Kazuyuki OHISHI, Junko IMAI and Masami MUKAI}

\author{
Faculty of Pharmaceutical Sciences, Okayama \\ University, Tsushima, Okayama 700, Japan
}

Received January 21, 1988

Cysteamine dioxygenase (CD, EC 1.13.11.19) catalyzes the conversion of cysteamine to hypotaurine. ${ }^{1 \sim 3)}$ The enzyme has been prepared in an almost homogeneous state from horse kidney ${ }^{4)}$ and hog liver, ${ }^{5)}$ and it required the presence of catalytic amounts of sulfide, elemental sulfur, selenium or hydroxylamine as a cofactor. ${ }^{1 \sim 3,5 \sim 7)}$ Trace amounts of taurine and thiotaurine were also produced as a side reaction by the further non-enzymatic change of hypotaurine. ${ }^{1,2,4)}$ This enzyme seems specific for cysteamine. Other thiol compounds such as cysteine and glutathione were not oxidized to their sulfinic derivatives by this enzyme. ${ }^{4)}$ The pathway of hypotaurine synthesis by $\mathrm{CD}$ has been found in some mammalian tissues, ${ }^{8,97}$ and it is considered as one of the main routes for taurine biosynthesis. ${ }^{10)}$ Taurine is present in relatively large amounts in various tissues, ${ }^{11,12)}$ and there is increasing evidence that this compound plays an important role in the body. ${ }^{13.14)}$ However, despite much research carried out on mammals and non-mammals, it is still not known whether taurine is the result of biosynthesis from sulfur-containing amino acids or of the diets provided to the animals. $\left.{ }^{15}, 16\right)$ Therefore, it seems important that the capacity of taurine biosynthesis in animal species and different tissues should be elucidated. Recently, we reported the distribution of taurine, ${ }^{12}$ hypotaurine ${ }^{17)}$ and cysteine sulfinate decarboxylase (CSD), ${ }^{181}$ which catalyzed the conversion of cysteine sulfinic acid to hypotaurine, in various animal tissues. In fish, invertebrates and mammalian hearts, the concentrations of taurine and hypotaurine were high, and CSD activity was not detectable. These findings suggested that other pathways could exist for the production of taurine in these animals. In this paper, we report the distribution of $\mathrm{CD}$ activity in various mammalian and non-mammalian tissues in order to estimate the capacity of taurine biosynthesis from cysteamine.

The tissues of two oxen, three pigs and five chickens were freshly supplied from local slaughterhouses. The tissues of the following animals were obtained by dissecting these animals in this labolatory: two male dogs, two male rabbits weighing $1.5 \sim 2.0 \mathrm{~kg}$, four male Wistar rats weighing $100 \sim 150 \mathrm{~g}$, eight male ICR mice weighing $20 \sim 25 \mathrm{~g}$, five mackerel weighing $200 \sim 300 \mathrm{~g}$, ten octopuses weighing $15 \sim 30 \mathrm{~g}$ and three cuttlefish weighing $250 \sim 300 \mathrm{~g}$. The preparation of the enzyme source was carried out by the procedure in the previous paper. Each tissue was homogenized in 5 volume of ice-cold $0.25 \mathrm{M}$ sucrose for 10 min using a Waring blender, and then the homogenate was centrifuged at $12,000 \times g$ for $30 \mathrm{~min}$ at $4^{\circ} \mathrm{C}$. The supernatant $(0.4 \mathrm{ml})$ was applied to a Sephadex G-25 column $(5.0 \mathrm{~cm} \times 0.9 \mathrm{~cm}$ i.d. $)$, and then the column was eluted with $10 \mathrm{~mm}$ phosphate buffer ( $\mathrm{pH} 6.8$ ) at a flowrate of $20 \mathrm{ml} / \mathrm{hr}$. The initial $1.6 \mathrm{ml}$ of the eluate was discarded and the following $2.4 \mathrm{ml}$ of the eluate was collected as the CD fraction. Through this column chromatographic procedure, the endogeneous hypotaurine and taurine, which would have rendered it difficult to perform an accurate assay of the low level of enzyme activity, were almost completely removed from the enzyme fraction. The process was completed within $15 \mathrm{~min}$ and no substantial loss of CD activity due to this treatment was observed. Protein concentration was measured by the method of Lowry et al. ${ }^{19}$ as modified by Miller ${ }^{20)}$ with bovine serum albumin as a standard. The reaction mixture contained $2 \mu \mathrm{mol}$ of cysteamine, $2 \mu \mathrm{mol}$ of $\mathrm{Na}_{2} \mathrm{~S}, 200 \mu \mathrm{mol}$ of phosphate buffer ( $\mathrm{pH}$ 6.4) and $0.1 \mu \mathrm{mol}$ of 3-amino-1propanesulfonic acid as an internal standard in a total

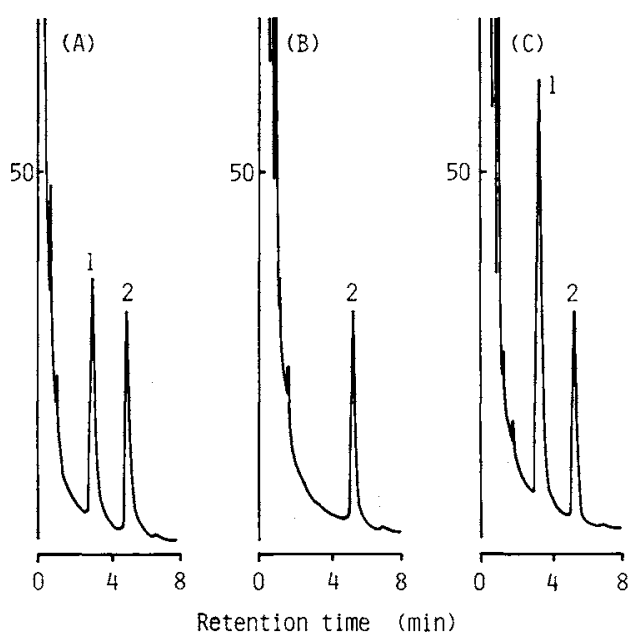

FiG. 1. Gas Chromatograms Obtained from (A) a Standard Solution (Containing $50 \mathrm{nmol}$ of Hypotaurine) and by an Assay of CD in Dog Kidney Incubated for (B) $0 \mathrm{~min}$ and $(\mathrm{C}) 30 \mathrm{~min}$.

GC conditions: apparatus, Shimadzu 4CM gas chromatograph equipped with a hydrogen flame ionization detector; column, 5\% SE-54 on Uniport HP (100 $120 \mathrm{mesh}), 1.0 \mathrm{~mm} \times 3 \mathrm{~mm}$ i.d. glass; column temperature, $235^{\circ} \mathrm{C}$, injection and detector temperature, $285^{\circ} \mathrm{C} ; \mathrm{N}_{2}$ flow-rate, $50 \mathrm{ml} / \mathrm{min}$. Peaks: $1=$ hypotaurine, $2=3$-amino1-propanesulfonic acid (internal standard). 
Table I. CD Activity in Various Animal Tissues

\begin{tabular}{lcccccccccc}
\hline \multirow{2}{*}{ Tissue } & \multicolumn{8}{c}{ CD activity $\left(\times 10^{-4} \mu \mathrm{mol} / \mathrm{min} / \mathrm{mg} \text { of protein }\right)^{a}$} \\
\cline { 2 - 6 } & Ox & Pig & Dog & Rabbit & Rat & Mouse & Chicken & Mackerel & Octopus & Cuttlefish \\
\hline Brain & $\mathrm{ND}^{b}$ & 2.8 & 2.1 & ND & ND & 1.7 & ND & 3.2 & - & - \\
Heart & 0.5 & 7.2 & 6.5 & 7.8 & 5.0 & 12.5 & 1.2 & 8.4 & 1.8 & 9.2 \\
Lung & ND & 1.6 & 2.0 & ND & 1.0 & 10.5 & 1.2 & - & - & - \\
Gill & - & - & - & - & - & - & - & 1.6 & ND & ND \\
Liver & 13.0 & 20.5 & 19.9 & 7.3 & 2.4 & 15.0 & 4.4 & 19.6 & 19.5 & 12.1 \\
Spleen & ND & 1.7 & 16.6 & 1.8 & 2.0 & 2.3 & 3.0 & 1.8 & - & - \\
Pancreas & 3.3 & ND & 10.3 & ND & ND & 6.9 & 3.4 & - & - & 8.5 \\
Kidney & 9.0 & 3.4 & 208.8 & 14.6 & 2.5 & 11.5 & - & 3.9 & 10.0 & 3.7 \\
Stomach & 2.5 & 11.7 & 23.5 & 7.7 & 4.8 & 13.6 & 1.3 & 3.7 & ND & ND \\
Intestine & - & - & - & - & 2.4 & 7.5 & - & - & - & - \\
Ovary & - & - & - & - & - & - & - & ND & ND & - \\
Testis & - & - & - & - & 0.7 & - & - & - & ND & - \\
Muscle & ND & ND & - & ND & ND & ND & ND & ND & ND & ND \\
\hline
\end{tabular}

" Each value represents the average obtained from three separate experiments.

$b$ Not detectable.

volume of $0.8 \mathrm{ml}$. After preincubating this mixture at $37^{\circ} \mathrm{C}$ for $5 \mathrm{~min}$, the assay was started with the addition of the enzyme solution (the $\mathrm{CD}$ fraction containing $0 \sim 1 \mathrm{mg}$ of protein). After incubating at $37^{\circ} \mathrm{C}$ for $30 \mathrm{~min}$, the reaction was terminated with $0.4 \mathrm{ml}$ of $0.15 \mathrm{M} \mathrm{H}_{2} \mathrm{SO}_{4}$, and the acidified mixture was then deproteinized by heating in a boiling water bath for $3 \mathrm{~min}$. After centrifugation at $2000 \times g$ for $5 \mathrm{~min}$, the protein-free supernatant was used for conversion, and the concentration of products was determined by the gas chromatographic method that was previously described. ${ }^{18)}$ Another tube that was not incubated served as the blank, and the blank value was subtracted from the value of the incubated sample. The products by the $C D$ reaction contained not only hypotaurine formed by the enzymatic reaction, but also trace amounts of taurine and thiotaurine formed by the nonenzymatic change of hypotaurine. Therefore, the total amount of these compounds had to be measured for CD activity. All the products could be converted into 2(isobutoxycarbonylamino)- $N, N$-dibutylethanesulfonamide by the method previously reported. ${ }^{18}$ Typical gas chromatograms obtained from a standard solution and by an assay of $\mathrm{CD}$ in dog kidney are shown in Fig. 1. The derivative obtained from the products formed by the $\mathrm{CD}$ reaction was eluted as a single and symmetrical peak, and no interfering peak was observed. The recovery rates of hypotaurine, taurine and thiotaurine added to the assay mixture containing dog kidney enzyme at $100 \mathrm{nmol}$ were $96.8 \pm 3.0 \%, 98.1 \pm 1.5 \%$ and $93.4 \pm 1.3 \%(n=3)$, respectively. These results indicate that the products formed by the $\mathrm{CD}$ reaction could be accurately and precisely determined, the detection limit for the products in the assay being about $5 \mathrm{nmol}$. The $\mathrm{CD}$ activities thus determined for various animal tissues by the method just described are summarized in Table I. CD activity was found in all the animals examined. Liver and kidney contained high activity, but brain and muscle contained very low or no activity. We recently reported the distribution of taurine, $^{12)}$ hypotaurine ${ }^{17)}$ and CSD activity ${ }^{18}$ in various animal tissues. Taurine and hypotaurine were widely found in the animal tissues examined. On the other hand, CSD activity was widely found in mammalian tissues, but it was not detectable in such non-mammals as fish and invertebrates. In mammalian tissues, liver and kidney contained high CSD activity, but heart contained very low or no activity. These results suggest that the pathway for hypotaurine synthesis differs with the source of animal and organ, and the pathway passing through cysteamine is important as an alternative pathway for taurine biosynthesis.

Acknowledgment. The authors wish to thank Professor M. Makita for his helpful discussions.

\section{REFERENCES}

1) D. Cavallini, C. De Marco and R. Scandurra, Ital. J. Biochem., 11, 196 (1962).

2) D. Cavallini, R. Scandurra and C. De Marco, J. Biol. Chem., 238, 2999 (1963).

3) R. Scandurra, R. Mosti and D. Cavallini, Ital. J. Biochem., 12, 361 (1963).

4) D. Cavallini, C. De Marco, R. Scandurra, S. Dupre and M. T. Graziani, J. Biol. Chem., 241, 3189 (1966).

5) R. B. Richerson and D. M. Ziegler, "Methods in Enzymology," Vol. 143, ed. by W. B. Jacoby and O. Griffith, Academic Press Inc., New York, 1987, p. 410 . 
6) D. Cavallini, R. Scandurra and G. Piccinini, Ital. $J$. Biochem., 14, 261 (1965).

7) D. Cavallini, R. Scandurra and C. De Marco, Biochem., J., 96, 781 (1965).

8) S. Dupre and C. De Marco, Ital. J. Biochem., 13, 386 (1964).

9) R. Huxtable and R. Bressler, "Taurine," ed. by R. Huxtable and A. Barbeau, Raven Press, New York, 1976 , p. 45.

10) D. Cavallini, R. Scandurra, S. Dupre, L. Santoro and D. Barra, Physiol. Chem. Physics, 8, 157 (1976).

11) J. G. Jacobsen and L. H. Smith, Physiol. Rev., 48, 425 (1968).

12) H. Kataoka, K. Ohishi, N. Inoue and M. Makita, Bunseki Kagaku, 34, 128 (1985).
13) K. H. Heyes and J. A. Sturman, Ann. Rev. Nutr., 1, $401(1981)$.

14) K. H. Heyes, Nutr. Rev., 43, 65 (1985).

15) R. Huxtable, J. Nutr., 111, 1275 (1981).

16) C. Portemer, Y. Pierre and F. Chatagner, Biochem. Int., 5, 105 (1982).

17) H. Kataoka, H. Yamamoto, Y. Sumida, T. Hashimoto and M. Makita, J. Chromatogr., 382, 242 (1986).

18) H. Kataoka, K. Ohishi, Y. Sumida, M. Ohmori and M. Makita, J. Chromatogr., 420, 135 (1987).

19) O. H. Lowry, N. J. Rosebrough, A. L. Farr and R. J. Randall, J. Biol. Chem., 193, 256 (1951).

20) G. L. Miller, Anal. Chem., 31, 964 (1959). 